\title{
LIVER TRANSPLANTION IN A PATIENT WITH RAPID ONSET PARKINSONISM-DEMENTIA COMPLEX INDUCED BY MANGANISM SECONDARY TO LIVER FAILURE
}

\author{
Giorgio Fabiani', Enio Rogacheski², Júlio César Wiederkehr³, \\ Jussara Khouri', Andréa Cianfarano ${ }^{4}$
}

\begin{abstract}
Bilateral and symmetric globus-pallidus hyperintensities are observed on T1-weighted MRI in most of the patients with chronic liver failure, due to manganese accumulation. We report a 53-year-old man, with rapid onset parkinsonism-dementia complex associated with accumulation of manganese in the brain, secondary to liver failure. A brain MRI was performed and a high signal on T1-weighted images was seen on globus-pallidus, as well as on T2-weighted images on the hemispheric white-matter. He was referred to a liver-transplantation. The patient passed away on the seventh postoperative day. Our findings support the concept of the toxic effects of manganese on the globus-pallidus. The treatment of this form of parkinsonism is controversial and liver-transplantation should not be considered as first line treatment but as an alternative one.
\end{abstract}

KEY WORDS: manganese, liver transplantation, parkinsonism-dementia, globus pallidus, high-signal.

\section{Transplante hepático em um paciente com complexo parkinsonismo-demência rapidamente pro- gressivo induzido por manganismo devido a insuficiência hepática}

\begin{abstract}
RESUMO - Hiperintesidades simétricas e bilaterais dos gânglios da base são observadas em imagens de ressonância magnética encefálica (RM) ponderadas em T1 na maioria dos pacientes com insuficiência hepática crônica devidas ao acúmulo de manganês. Nós relatamos o caso de um homem, com 53 anos de idade, com um complexo parkinsonismo-demência rapidamente progressivo associado com o acúmulo de manganês no cérebro, secundariamente a insuficiência hepática. Uma RM encefálica foi realizada e foram observadas imagens hiperintensas/hipersinal nas imagens ponderadas em T1 no globo pálido e, também, na substância branca dos hemisférios cerebrais ponderadas em T2. Devido à falta de resposta ao tratamento clinico optamos pelo transplante hepático. O paciente faleceu no $7^{\circ}$ dia de PO. Nossos achados corroboram o conceito dos efeitos tóxicos do manganês nos gânglios da base/globo pálido. $O$ tratamento desta forma de parkinsonismo é controverso e o transplante hepático não deverá ser considerada uma opção terapêutica de primeira linha, porém como um tratamento alternativo considerando-se os riscos-benefícios dessa escolha.
\end{abstract}

PALAVRAS-CHAVE: manganês, transplante hepático, complexo parkinsonismo-demência, globo pálido.

Parkinson's disease (PD) is an age-related and progressive neurodegenerative disorder characterized by asymmetric onset of rest tremor, rigidity, bradykinesia and postural instability ${ }^{1,2}$. To the moment there are no known causes for PD but genetic and environmental factors play an important role in the pathogenesis ${ }^{1,3,4}$. Parkinsonism is a syndrome that resembles PD and is classified as primary / idiopathic and secondary. There are several causes for secondary parkinsonism: infectious or post-infectious, inflammatory, drug-induced, toxic, metabolic, familial are the most important ${ }^{3-6}$. Manganese (Mn) is the most common known environmental cause of parkinsonism $^{3-6}$. The symptoms are slightly different from the idiopathic parkinsonism. Acute, high-level occupational manganese exposure causes a clinically distinct syndrome (Manganism) characterized by progressive parkinsonism, dystonia and neuropsychiatric symp-

\footnotetext{
${ }^{1}$ Department of Neurology - Hospital de Caridade da Irmandade da Santa Casa de Misericórdia de Curitiba - Pontifícia Universidade Católica do Paraná, Curitiba PR, Brazil (PUCPR); ${ }^{2}$ Department of Radiology, Federal University of Paraná (UFPR) and DAPI - Diagnóstico Avançado por Imagem, Curitiba PR, Brazil; ${ }^{3}$ Department of Surgery and Hepatic Transplantation, UFPR, Hospital de Caridade da Irmandade da Santa Casa de Misericórdia de Curitiba, PUCPR, Curitiba PR, Brazil; ${ }^{4}$ Resident in Radiology at DAPI, Curitiba PR, Brazil.
}

Received 7 December 2006, received in final form 26 February 2007. Accepted 19 April 2007. 
toms $\mathrm{s}^{4-8}$. The accumulation of manganese in the brain, mainly in the basal ganglia is a variant of hepatic encephalopathy (HE).

The treatment is controversial. As a first step clinical treatment must always be targeted. Finsterer et al. reported recovery of parkinsonian syndrome on a patient submitted to L-dopa, pramipexole and L-ornithin-L-aspartate treatment. Rocha et al. reported an interesting case of reversible parkinsonism and port systemic encephalopathy following embolization of a congenital intrahepatic venous shunt. Nonetheless these evidences, liver transplantation might be the only choice for some patients; even though the parkinsonian and the neuropsychiatric changes might persist even after liver-transplantation in some patients ${ }^{9-11}$.

\section{CASE}

A 53-year-old man with a prior history of alcoholic cirrhosis, esophageal varices and portal hypertension was referred to our service because progressive slowness of body movements, rigidity, tremors in the upper limbs, postural instability, frequent fallings, slurred speech, micrographia, emotional lability, forgetfulness that started six months before his hospital admission. He was alcoholic for almost 40 years until the symptoms began. An extensive environmental and occupational history did not detect any external source of Mn. Neurological examination demonstrated a patient with mask-face, a Mental State Examination (MSE) with 12 points, dysarthria, tremor, bradykinesia and cogwheel rigidity, parkinsonian gait, postural imbalance and bilateral signs of upper-motor-neuron compromise, all the symptoms were worse on the right side. The Hoehn and Yahr (HY) scale stage was 3. Laboratory exams and liver function disclosed mild abnormalities and he was classified as Child-Pugh A. Whole blood Mn was higher than 50 ug/L. Serum ammonia was 36 (normal $10-40 \mathrm{mmol} / \mathrm{L}$ ), prothrombin time was normal (12 seconds). MRI demonstrated increased signal intensity on T1-weighted images on globus pallidus (GP) and on the midbrain (substantia nigra) (Fig 1), as well increased signal intensity on T2-weighted and FLAIR sequences in hemispheric white-matter, seen as hypodensities on non-enhanced CT scan (Fig 2).

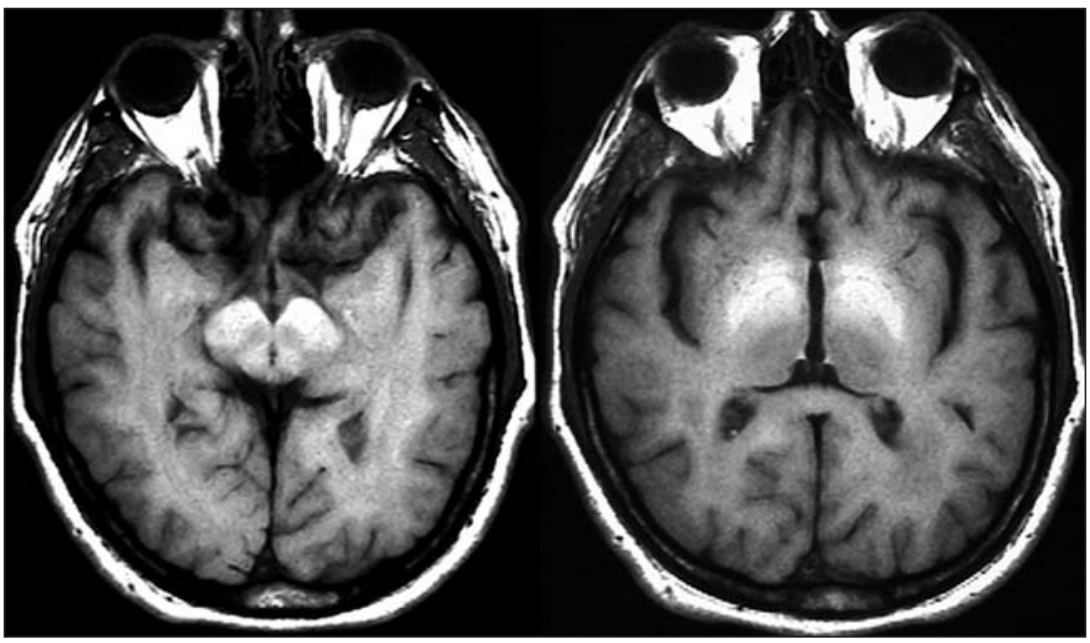

Fig 1. MRI demonstrated increased signal intensity on T1-weighted images on globus pallidus (GP) and on the midbrain (substantia nigra).

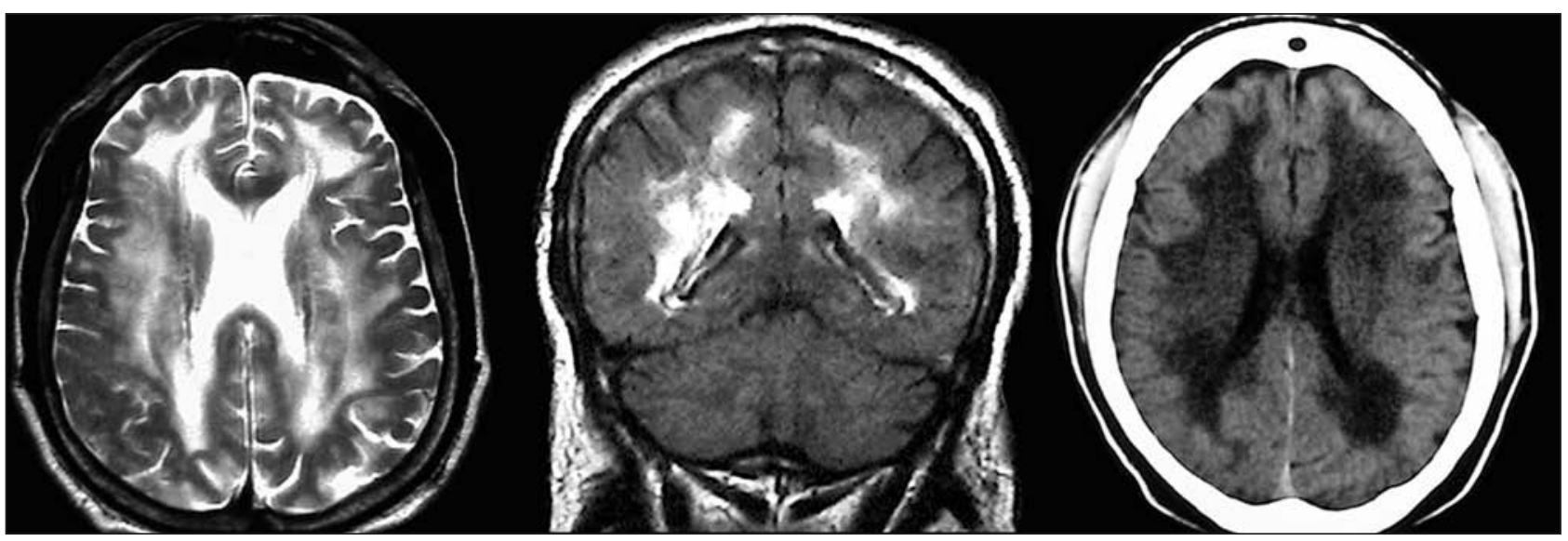

Fig 2. Increased signal intensity on T2-weighted and FLAIR sequences in hemispheric white-matter, seen as hypodensities on nonenhanced CT scan. 


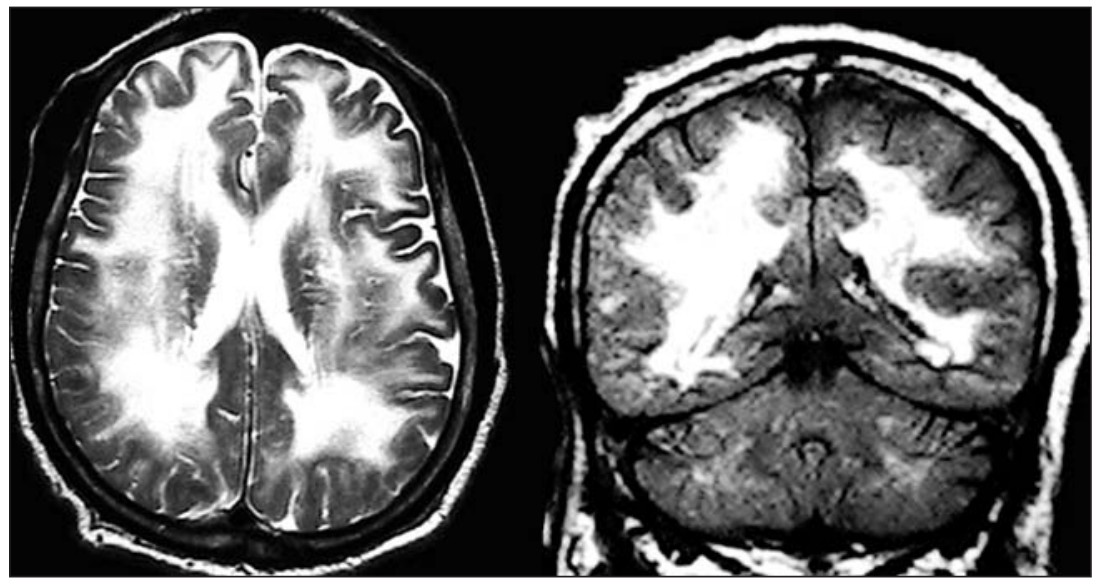

Fig 3. The last MRI clearly demonstrated worsening of the lesions, mainly on T2weighted images involving the hemispheric white-matter.

Based on the reports of Vogels and Koller, respectively, that first tried a treatment with L-Dopa and memantine with encouraging results; we decided on to treat the patient clinically and he was given carbidopa/L-dopa up to $500 \mathrm{mg} /$ day and memantine $20 \mathrm{mg} /$ day. The patient presented only a partial and not sustained recovery of the motor signs such as gait, balance, bradykinesia, and less of the neuropsychiatric symptoms. Although the week effects of this therapy the patient showed considerable worsening of the symptoms every time the drugs were interrupted; the treatment was maintained for almost 6 months, until the surgery ${ }^{12,13}$. A complete follow-up assessment was done six months later, when new exams were performed. The tests demonstrated worsening of all aspects of the process. The MSE decreased to only 5 points and the HY scale stage increased to 4 . The last MRI clearly demonstrated worsening of the lesions, mainly on T2- weighted images involving the hemispheric white-matter (Fig 3).

As the patient worsened despite the treatment, the medical team with agreement of the patient's family, decided on for a liver transplantation (inter-vivo) with his son as the donor. The decision to the surgery came after a complete psychological approach of the family and the donor; the family gave us a signed consent accepting the surgery as a last effort of treatment and all their members were aware of the hazards. The surgery was approved by the ethical committee of the Hospital. Unfortunately, the patient developed an acute rejection and generalized sepsis that resulted in his death on the $7^{\text {th }}$ postoperative day.

\section{DISCUSSION}

Patients with HE usually develop tremors. Most of them show at least the "mini-astherixis". Timmermann et al. compared tremor syndromes in parkinsonian patients with a typical resting tremor and in patients with hepatic encephalopathy using magneto-encephalography ${ }^{14}$. The study revealed the existence of different mechanisms of tremor generation in parkinsonian patients and those with HE. In parkinsonian patients there was a strong coherence between the electromyography of forearm muscles and activity in the contralateral primary motor cortex at tremor frequency and also at double tremor frequency. This phenomenon was not observed in patients with $\mathrm{HE}$.

Our patient was submitted to the usual treatment for hepatic encephalopathy; simultaneously he received L-Dopa and memantine, with poor results. As the patient worsened rapidly, clinically and objectively as demonstrated by the new MRI exam, the liver-transplantation was imperative.

This is not the first attempt to treat a parkinsonian syndrome by liver transplantation, but to best of our knowledge, this is the first report of an attempt to treat a parkinsonian plus dementia syndrome, rapidly and inexorably progressive secondary to a cirrhotic accumulation of $\mathrm{Mn}$ in the brain, with liver transplantation. It was clearly demonstrated that the brain changes in this patient with chronic liver failure, were due to accumulation of $\mathrm{Mn}$, as well as the probable brain swelling in the hemispheric white-matter.

Bilateral symmetric hyperintensities of the globus pallidus are observed on T1-weighted MR images in the majority of patients with chronic liver failure. This occurs secondarily to accumulation of manganese in the brain produced by liver failure due to billiary excretion deficiency ${ }^{3-8}$. Significant T2-weighted signal abnormalities are usually demonstrated. It has been suggested that mild astrocytic swelling occurs in chronic liver failure and these changes could be responsible for the T2- weighted abnormalities ${ }^{4-8}$. Rovira et al. clearly demonstrated this MRI finding in patients with chronic liver failure: the high-signal intensity along the hemispheric white matter in corticospinal tract on T2-weighted images and it was at least partially reversible by liver transplantation ${ }^{8}$.

A recently published functional study with $\left[{ }^{18} \mathrm{~F}\right]$ 
FDOPA PET demonstrated relatively symmetric and severely reduced $\left[{ }^{18} \mathrm{~F}\right]$ FDOPA levels in the posterior putamen compared to controls, in patients with parkinsonism due to manganism. The GP had increased signal on T1-weighted MRI images. The authors concluded that elevated $\mathrm{Mn}$ exposure may be associated with reduced striatal $\left[{ }^{18} \mathrm{~F}\right]$ FDOPA uptake, and MRI is useful to reveal selective abnormality within the internal segment of the globus pallidus ${ }^{7}$.

In conclusion, our patient presented with a rapid onset PK-dementia complex associated with accumulation of $\mathrm{Mn}$ in the brain, secondarily to chronic liver failure. The parkinsonian symptoms were identical to those found in typical idiopathic parkinsonian patients. The tremor in no moment resembled the postural tremor called "mini-asterixis". There was a great expectation in the medical team that the liver transplantation could stop the neurological deterioration in a first moment and later it would completely reverse the process, according to some reports published. Our findings support the concept of the toxic effects of Mn on the GP and SN. We suggest that the liver-transplantation should not be considered as first line treatment but as an alternative one, when the symptoms are irresponsive to the clinical treatment.

\section{REFERENCES}

1. Hughes AJ, Daniel SE, Lees AJ. Improved accuracy of clinical diagnosis of Lewy body Parkinson's disease. Neurology 2001;57:1497-1499.
2. Jankovic J. Searching for a relationship between manganese and welding and Parkinson's disease. Neurology 2005;64:2021-2028.

3. Racette BA, McGee-Minnich L, Moerlein SM, Mink JW, Videen TO, Perlmutter JS. Welding-related parkinsonism: clinical features, treatment, and pathophysiology. Neurology 2001;56:8-13.

4. Calne DB, Chu NS, Huang CC, Lu CS, Olanow W. Manganism and idiopathic parkinsonism: similarities and differences. Neurology 1994;44: 1583-1586.

5. Inoue E, Hori S, Narumi Y, et al. Portal-systemic encephalopathy: presence of basal ganglia lesions with high signal intensity on MR images. Radiology 1991;179:551-555.

6. Burkhard PR, Delavelle J, Du Pasquier R, Spahr L. Chronic parkinsonism associated with cihrrosis: a distinct subset of acquired hepatocerebral degeneration. Arch Neurol 2003;60:521-528.

7. Racette BA, Antenor JA, McGee-Minnich L, et al. $\left[{ }^{18} \mathrm{~F}\right]$ FDOPA PET and clinical features in Parkinsonism due to manganism. Mov Disord 2005; 20:492-496.

8. Rovira A, Cordoba J, Raguer N, Alonso J. Magnetic resonance imaging measurement of brain edema in patients with liver disease: resolution after transplantation. Curr Opin Neurol 2002;15:731-737.

9. Finsterer J, Bernauer E. Recovery from parkinson syndrome and prolonged visually evoked potentials in hepatic encephalopathy. Metab Brain Dis 2005;20:55-60.

10. Rocha AJ, Braga FT, Silva CJ, et al. Reversal of parkinsonism and port systemic encephalopathy following embolization of a congenital intrahepatic venous shunt: brain MR imaging and $1 \mathrm{H}$ spectroscopic findings. Am J Neuroradiol 2004;25:1247-1250.

11. Lazeyras F, Spahr L, DuPasquier R, et al. Persistence of mild parkinsonism 4 months after liver transplantation in patients with preoperative minimal hepatic encephalopathy: a study on neuroradiological and blood manganese changes. Transpl Int 2002;15:188-195.

13. Vogels BA, Mass MA, Daalhuisen J, Quack G, Chamuleau RA . Memantine, a noncompetitive NMDA receptor antagonist improves hyperammonemia-induced encephalopathy and acute hepatic encephalopathy in rats. Hepatology 1997;25:820-827.

12. Koller WC, Lyons KE, Truly W. Effect of levodopa treatment for parkinsonism in welders: a double-blind study. Neurology 2004;62:730-733.

14. Timmermann L, Gross J, Butz M, et al. Pathological oscillatory coupling within the human motor system in different tremor syndromes as revealed by magnetoencephalography. Neurol Clin Neurophysiol 2004; $30: 26$. 